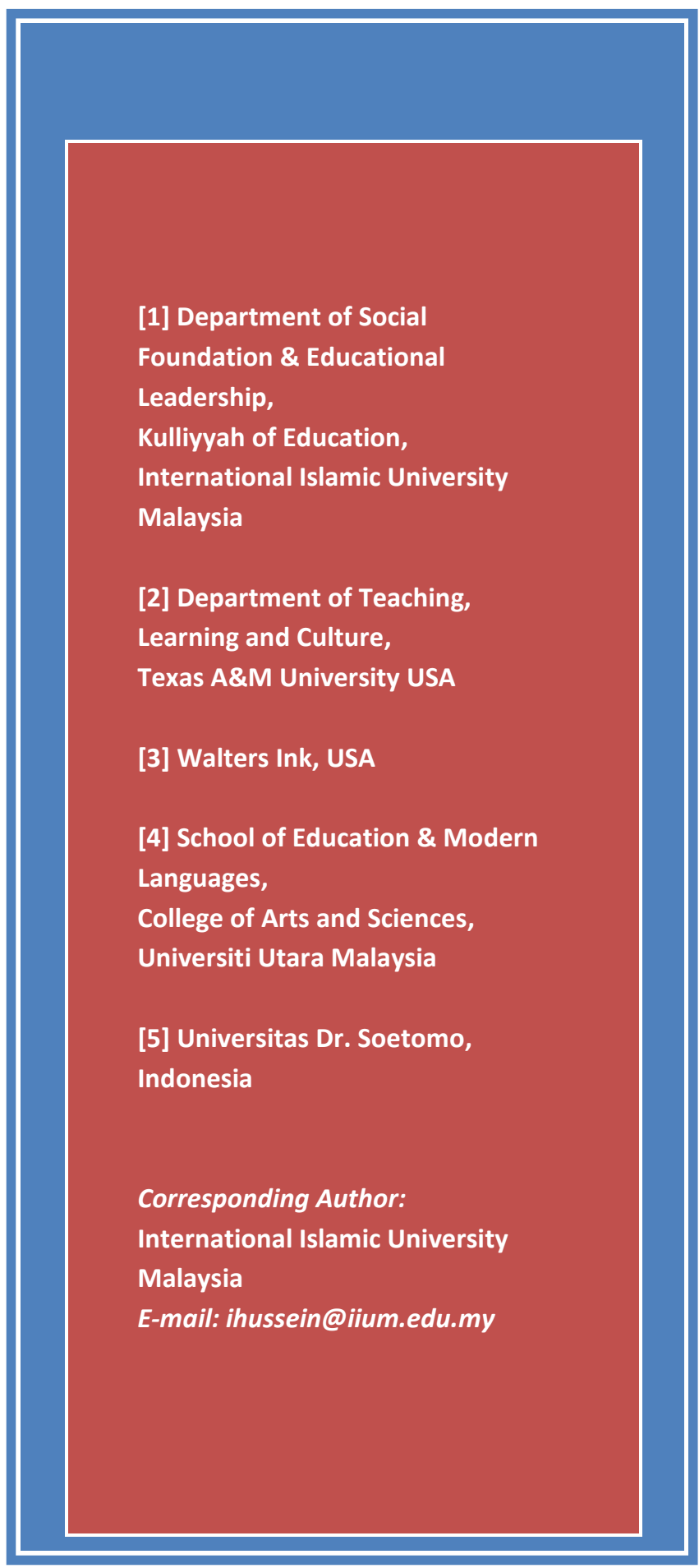

\section{R-SEECKA MODEL FOR RESEARCH SUPERVISION AND THE EFFECT ON ACADEMIC AND CAREER GROWTH OF INTERNATIONAL GRADUATE STUDENTS IN MALAYSIA}

Ismail Hussein Amzat $(\mathrm{PhD})^{1}$, Lynne M. Walters $(\mathrm{PhD})^{2}$, Tim Walters ${ }^{3}$, Byabazaire Yusuf $(\mathrm{PhD})^{4} \&$ Muhajir Teslikhan ${ }^{5}$

[1] Department of Social

Foundation \& Educational

Leadership,

Kulliyyah of Education,

International Islamic University

Malaysia

[2] Department of Teaching,

Learning and Culture,

Texas A\&M University USA

\section{[3] Walters Ink, USA}

[4] School of Education \& Modern

Languages,

College of Arts and Sciences,

Universiti Utara Malaysia

[5] Universitas Dr. Soetomo, Indonesia

Corresponding Author:

International Islamic University

Malaysia

E-mail: ihussein@iium.edu.my 


\section{MALAYSIAN ONLINE JOURNAL OF EDUCATIONAL MANAGEMENT (MOJEM)}

\section{INTRODUCTION}

Around the world, postgraduate supervision in higher education has been scrutinized, and the demand is for a process that is transparent, rigorous, and supportive to meet the expectation of students across international boundaries (Sidhu, Kaur, Fook, \& Yunus, 2013). Students writing their thesis must have a good relationship with their supervisors, not only for the thesis progress and completion in the doctoral experience, but success in student's doctoral programme and academic career. Therefore, emphasis has been placed globally on providing formal training to research supervisors on monitoring and accountability (Halse, 2011; Higher Education Academy, 2014).

In general, proper and close research supervision plays critical role in the academic life and success of a graduate student. Advisor support is likely to play a key role in the experiences of doctoral students, as they navigate their way through graduate school, develop a sense of belonging, and view themselves as competent and productive members of the academy (Curtin, Stewart, \& Ostrove, 2013). With less social support, international graduate students tend to have difficulties managing the many challenges they may face in their host institution and country during their studies and may value and rely more on advisor support (Curtin et al., 2013). Conversely, a poor relationship might lead students to abandon the host country and their studies or programs (Terrell, Snyder, \& Dringus, 2009).

In Malaysia, higher education has undergone dramatic changes since the launching of the National Higher Education Strategic Plan in 2007. This plan proposed to develop human capital and make Malaysia a regional educational hub. It was followed by the Malaysian Ministry of Education's (MOE) Internationalization Policy, which, thus far, seems to have been successful. In 2019, Malaysia had 135,000 international students, most coming from Bangladesh, Indonesia, China, Nigeria, India, Pakistan, Yemen, Kazakhstan, Sri Lanka and Libya.

According to UNESCO's latest Student Mobility Survey, Malaysia has risen from twelfth to ninth place in terms of the number of international students, becoming an education centre in Southeast Asia and a global top destination for post-secondary education (ICEF Monitor, 2016). However, attracting international students is only the beginning; there should be effective strategies to retain them, ensure the smoothness of their studies and academic growth and wellbeing. This is important because, as research has shown, international students face physical, social, and economic problems as they attempt to adapt to the Malaysian culture, cuisine and climate and to learn a new language (Zuria, Salleh, Saemah, \& Noriah, 2010).

In terms of research supervision as perceived by international students in Malaysia, the study by Krauss and Ismail (2010) used qualitative methods with international students from different countries. The authors reported that managing personal relations with the supervisors, time and accessibility of the supervisors, constraints, academic compatibility and expectations were issues the students raised by the 18 students in their study. Al-Naggar, AlSarory, Al-Naggar, and Al-Muosli (2012) conducted another study on international doctoral students' satisfaction and stress related to academic supervision in Malaysian universities. Using qualitative methods, he reported that majority of the participants were anxious about the research supervision process and the lack of advice from their supervisors regarding their research topics, dissatisfied with their supervisors in terms of monitoring, progress, and unrealistic time frames for completion of their research.

Since the internationalization of higher education in Malaysia, a plethora of studies have been conducted to investigate international students' adjustment in Malaysia. As reported and cited by Othman (2015), international students faced issues related to "cultural challenges and care (Mahmud et al., 2010); social support (Yusliza, 2010); academic, religious, personal, and social adjustment problems (Malaklolunthu \& Selan, 2010); cost of living (Malaklolunthu \& Selan, 2010; Asgari \& Borzooei, 2014); social, recreational, curriculum, and method of teaching (Alavi \& Mansor, 2011); multiculturalism, discrimination, academic, social support networks (Pandian, 2008); academic adjustment (Safahieh \& Sigh, 2007); the environment (Desa, Yusoff, \& Kadir, 2012; Yee, 2013); attitude 


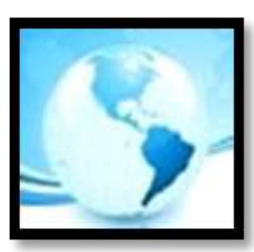

\section{MALAYSIAN ONLINE JOURNAL OF EDUCATIONAL MANAGEMENT (MOJEM)}

(Desa et al., 2012), livelihood (e.g., transportation and immigration service, community condition), service, and facilities (Jani et al., 2010); festival, event, facility, and accommodation" (Asgari \& Borzooei, 2014; p6).

\section{LITERATURE REVIEW}

\section{Postgraduate Mentor and Mentee Program in Malaysia}

Academic supervision, or mentoring, at universities has several aims. The process should enable a student to adapt to the academic culture of the university, lead to academic achievement, and contribute to career planning and development. The supervisor should help a graduate student throughout the scientific research process, allowing a novice scholar to develop a sense of belonging to academic society. Most importantly, the supervisor should collaborate with students, making it possible for them to conduct and disseminate new research and advance the academic careers of both mentor and mentee (Ramesh, 2014). Nevertheless, the role played by the supervisor, or mentor, is complex and requires a multiplicity of skills. He or she must be a teacher, a leader, a friend, a guide, a coach, and a colleague (Jonson, 2008). Thus, a good mentor: 1) has effective communication skills, 2) is open to strong interpersonal relationships, 3) has standing in a well-respected position, 4) is willing to learn and teach, 5) is self-confident, empathic, and patient, and 6) is the sponsor and protector of the young people he or she supervises (Cinar, 2007; Clutterbuck, 2004; Jonson, 2008; Karakose, Y irci, Uygun, \& Ozedmir, 2016; Schein, 1978).

In Malaysia, all public and private universities provide postgraduate programs, whose duration differs according to the student's academic status and discipline. There are master's programs for one-year (two semesters), with a two-year (four semester) maximum. The doctoral program is completed in a minimum of two years of coursework, and/or rigorous research. Master's and doctoral students, in full research mode, usually are expected to defend the proposal at the completion of the second semester and the Viva Voce examination for thesis/dissertation defence. Doctoral students in Malaysia are required to submit not less than 200 thesis pages, while fewer pages are required of the master's student. At the doctoral level, postgraduate thesis guidance is carried out by main supervisor and co-supervisor, while only a main supervisor is assigned to direct the master's thesis. Because of the centralized educational system, all universities in Malaysia are expected to have a similar style of supervision, research programme and structure.

Overseas universities with established branches in Malaysia, such as the University of Nottingham Malaysia, Monash University Malaysia, and the University of Southampton Malaysia, have put post-graduate mentor/mentee programs into operation by launching a program called "MyMentor," which the Malaysian Ministry of Education supports and regulates. The MyMentor program aligns with the National Higher Education Strategic Plan to produce talented PhD students and world-class researchers whose work will raise the rankings of Malaysian universities.

As the number of postgraduate student programmes and activities has increased, so does the possibility that the nation will achieve its dream of becoming a developed nation by 2020. Nonetheless, several basic questions remain which are: What are the personal benefits that accrue to international students for their contributions to the Malaysian plan? To what extent has a program like MyMentor been established in Malaysian public universities? Does this program consider the research progress of international students and their supervision, enabling to reach their goals and graduate on time?

These are important questions to answer, for research has shown that constant research monitoring, thoughtful supervision, and the availability of faculty members are essential for an effective graduate program (Donald, Saroyan, \& Denison, 1995). The apprenticeship model of most PhD programs means that the relationship between a doctoral student and his or her advisor is a key aspect of both satisfaction and success (Lovitts, 2001). Guven (2014) examined mentoring relationships between graduate students and their supervisors. According to the study, several problems can be encountered during the academic mentoring process in universities. Workloads of 


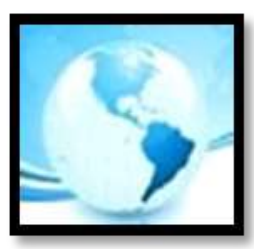

\section{MALAYSIAN ONLINE JOURNAL OF EDUCATIONAL MANAGEMENT (MOJEM)}

faculty members may be high, with instructors having to cope with the often-overwhelming demands of teaching, research and service. Thus, they may have little time to spare for their graduate students, even less if the supervisors also have administrative duties. If they are to devote this kind of time and effort to mentorship, they must get something out of the relationship as well, such as financial rewards, academic recognition, or contributions to their own research progress.

Because of these issues, several research studies have indicated that a high proportion of postgraduate students are unable to complete their studies within the stipulated time. Among the several factors thought to contribute to this scenario the most important is the supervision that they receive (Hussain, 2011). A competent supervisor plays an essential role in a student's successful completion of his/her research program (Hunter, Laursen, \& Seymour, 2006). However, in many cases, how well graduate students are supervised depends on the way in which a student chooses to fulfil his/her part of the responsibility. A supervisor's role is to deal with the mechanics of ensuring that a student makes steady progress towards completing his or her research (Ismail, Abiddin, \& Hasan, 2011). This means that, if a student is not proactive and self-directed towards achieving research goals, a supervisor may face a huge challenge in doing his or her job effectively.

\section{Relationships in Supervision and Expectations}

The connection between supervisor and supervisee goes beyond merely academic. It is a dyadic relationship that could last long after a student's graduation. Whether this occurs depends on the type of supervision provided by the mentor and on whether the students see the supervision meeting his/her expectations. Holloway (1995) explains the artistry of supervision as being able to offer consultation opportunities based on appointments made by students for seeking advice and guidance regarding their research projects. The relationship they build with their faculty advisor is dependent on their understanding of the formal roles and responsibilities and the academic expectations of their advisors, as well as on the faculty member's advising philosophy. It is therefore important to continually remind international graduate students about their responsibilities and those of their advisors (Omar, Mahone, Ngobia, \& FitzSimons, 2016).

Under normal circumstance, the relationship between the graduate student and his/her supervisor is expected to be a good one, and any changes in the method of supervision or rules should be drawn in favour of the supervisee's interests, or at least not hinder the personal and professional development of that student. Moreover, because this is a contractual relationship, the outcome, especially on a graduate level, is to achieve the university's academic goals by producing scholars, researchers, and practitioners (Chiappetta-Swanson \& Watt, 2011).

The expectations of students could influence the supervisory style, either directly or indirectly. To meet the supervisee's learning and research needs, a supervisor must be willing to make necessary adjustments in establishing a favourable academic relationship (Hodza, 2007). For this to happen, graduate schools should provide sufficient information about faculty to enable students, who have the ability to choose their own supervisors (and not all do), find a mentor whose research interests compliment their own. On their part, faculty members should be readily accessible to students who are in the process of choosing a supervisor or mentor to determine if there is a personal and professional connection (Ismail et al., 2011). This is critical, especially for an international student who is new to the country and program. If there is a disconnect because the supervisor and the student do not know each other that well, the mentoring relationship can be weak and the careers of both supervisor and student can suffer (Karakose, 2016).

Conversely, students have their own expectations about the supervision process. International doctoral students view their advisors as potential sources of information and support as they navigate graduate school (Curtin et al., 2013). Based on a simple indicative survey, Hussain (2011) found that students look for supervisors who are skilled and can inspire and build their confidence. Their interest is in finding potential supervisors who are both 


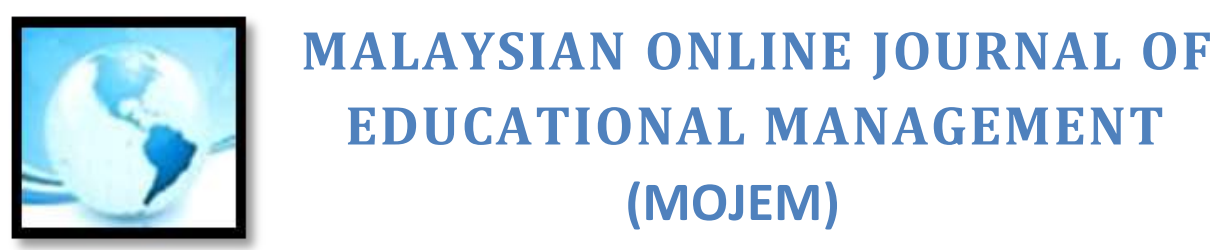

knowledgeable and have an interest in the research area. Such supervisors should have adequate time for their students. Giving timely and constructive feedback, supervisors help students improve their research and writing (Ali, Watson, \& Dhingra, 2016). Otherwise, poor supervision could lead to anxiety and uncertainty on the part of the student.

A supervisor whose research skills match the student's needs and whose research area matches the student's interests can help that young person reduce and manage uncertainty and transformations. A student should be made to understand what the study area is about. Also, the topic and scope of research, as well as the methodology, should be clarified at the earliest stage. As for managing transformations, a supervisor must help a student turn an uncertain feature into a concrete work plan by zeroing in on a specific problem with defined objectives and deliverables (Hussain, 2011). Mentoring and supervision enhances postgraduates' research skills, sharing experiences and foster positive relationships (Mudhovozi, Manganye, \& Mashamba, 2017). The relationship between student and supervisor is a professional one in which a supervisor plays a big role of helping students acquire research skills without jeopardizing their intellectual and personal development (Donnelly, 2012).

Wang and Li (2014) looked at international postgraduate research students' challenges in writing a thesis in Australia, which has with huge number of international students. They found that competence and confidence in academic writing are among the major problems facing students from non-English speaking backgrounds. Supervising PhD research is considered challenging because the doctorate is academia's highest qualification, and the students should be the most intellectually advanced. In that regard, a PhD supervisor should be an expert in the area of the students' interest, and should be able to provide continuous guidance and support of all thesis writing aspects, such as writing a problem statement and a literature review, and ensuring that the thesis contributes new knowledge (Hamilton \& Carson, 2015). This can only take place when there is a professional relationship between supervisor and supervisee, and the supervisor is committed to the management of student work. Through academic or interpersonal interaction, a supervisor should be aware of the knowledge and skills the student brings to the classroom and research project. This will allow the supervisor to focus his/her efforts on the areas in which the student most needs help and support (Chiappetta-Swanson \& Watt, 2011). Furthermore, although the temptation for students is to apportion blame to supervisors for their failures, how well students are supervised often depends on how well students fulfil their responsibilities as researchers in training.

\section{Research Supervisors' Content Knowledge and Campus Environment and Facilities}

The search for the variables that should go into a model of effective supervision has been going on for some time. Based on the available literature, the variables can be narrowed down into a few key criteria. First, the supervisor's background knowledge and skills are reported to play a major role in the effectiveness of the research supervision and the students' ability to graduate on time. Research conducted by Ghadirian, Sayarifard, Majdzadeh, Rajabi, and Yunesian (2014) reported that the absence of supervisory and research knowledge and skill in the thesis area was one of the reasons for a student's poor project management. Students also complained about the supervisor's lack of time and knowledge of their research methodology. Supervisor's knowledge transfer to the supervisee was also reported as important for postgraduates in a research done in Malaysia on postgraduate supervision (Sidhu et al., 2013).

Ali et al. (2016) conducted a research with 131 postgraduate students and 77 supervisors in the United Kingdom. The authors reported that, both supervisors and supervisees agreed that a supervisor should be interested in the student's research, available for students, and provide constructive feedback. Besides, the supervisor should help students in time management, in their learning needs, to be independent and able to present their work. They need to be open minded, willing to admit mistakes, be motivated and enthusiastic about research (Tahir, Ghani, Atek, \& Manaf, 2012). The authors also suggested the implementation of a new research supervisor pedagogy that emphasizes "dissensus" and support to supervisees managing complexity, ambiguity, conflict, uncertainty, and difference (Andreotti, 2011; Grant, Hackney, \& Edger, 2014). Hence, familiarity with knowledge analysis, 


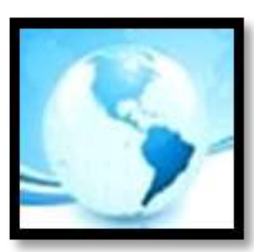

\section{MALAYSIAN ONLINE JOURNAL OF EDUCATIONAL MANAGEMENT (MOJEM)}

techniques and research methods contributes to an effective supervisor. Based on this view, first-hand research experience is a key component of the supervision process.

Inasmuch as the success of postgraduate education depends on effective and efficient supervision (Alam, Alam, \& Rasul, 2013), the ability to meet university standards of "publish and perish" before PhD completion could serve as an indication of effective supervision. Thus, it could be seen as an assessment of whether the supervisees have learned something, or been equipped with research skills, when seeing them present their work in seminars and publishing in reputable journals. This approach encourages students to discuss their research in a proper forum, helps in overcoming isolation by networking with other students and staff, enhances collaboration and scholarly debate, and opens the window for collegial participatory learning. Seminars are ideal for honing student skills as researchers, scholars, and presenters. They bring other research faculty into the process. This is enormously beneficial to the students, as one supervisor alone cannot equip all of his/her charges with all the skills needed for success in the world of academia (Ismail et al., 2011).

Malfroy (2005) suggests that an open approach to supervision and a collaborative approach to learning may be better in helping students develop research skills than more traditional supervisor-directed methods. Zuber-Skerrit and Roche (2004) outlined some other qualities of an effective postgraduate supervisor, including being resourceful, highly organized, supportive, and directed by a student's needs. This suggests that, when a skilful academic research supervisor is in charge, a postgraduate student would not be isolated, anxious, confused, or faced with uncertainly and time management issues during the research period. The academic environment plays a big role in the student's satisfaction with the research process and the institution. In the study by Sidhu et al. (2013) on postgraduate supervision among Malaysians, the research environment was reported among of the challenges faced by students, especially were completing their work. Hence, they felt that generally, institutional support was low, and they suggested better postgraduate centres with flexible financial packages to create better learning communities for postgraduates.

This is especially important for international students in an unfamiliar environment, who, without proper guidance, may fail to matriculate on time or complete their research, drop out, or be terminated by the program. The responsibility for a student finishing on time lies not just with the student; it is in the hands of the supervisor and his or her supervision strategies.

\section{Supervision: Encouragement, Support and Academic Growth}

The university's international policy initiatives have emphasized shifting the research focus on personal development. As stated in the policy paper of the League of European Research Universities:

Doctoral programmes prepare researchers to the highest level to make important contributions to frontier research. In addition, doctoral graduates are well prepared to take up roles in driving complex changes in society.... Doctoral graduates deliver the advanced research skills necessary in professional sectors beyond frontier research and education: in applied research, in policy making, in management, and in many other leadership roles in society (Åkerlind \& McAlpine, 2015, p2).

A study by Roberts and Seaman (2018) on dissertation supervision reported that good supervision takes place when both supervisor and student share the research interest. Student academic and personal growth are fostered when supervisors give students are given advice and support, without undermining the students' ownership of projects. However, the supervision practices generally are not stated in university policies, rather they develop over time and change with circumstances. Grant et al. (2014) reported on the "policy cycle" created by universities in the United Kingdom" to assist supervisors in working effectively with their postgraduate students. Some elements of the policy are listed below: 


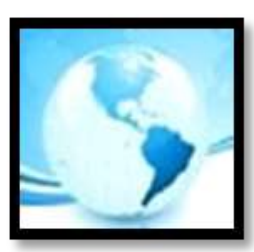

\section{MALAYSIAN ONLINE JOURNAL OF EDUCATIONAL MANAGEMENT (MOJEM)}

- Supervisors should provide academic advice and guidance to their research students.

- Supervisors should assist students on their social issues such as personal, health, or financial problems by recommending appropriate trained agencies to approach.

- $\quad$ Supervisors should support students in developing their career during candidature and beyond.

- Constructive and critical assessment should be provided by the supervisor to improve the candidate's work.

- Supervisors should promptly advise students if the progress in their research is not satisfactory, and provide guidance, as well as advice, on the thesis format.

- Supervisors should assist students in the identification of the ethical and intellectual property issues, while informing them of the consequences of the misconduct.

From this policy, it can be seen that, supervisors play a crucial role in the student's research completion, academic success, and career development. According to this policy, supervisors are full-service mentors for their students, providing everything from academic support to social support. Supervisors are charged not only with the transfer of research and related skills to students, but as a link to connect and engage educators and students. To develop next generation practitioners that have educational skills that the future needs, it is necessary the faculty play a role in providing supportive, constructive supervision engagement (Van Rensburg, Mayers, \& Roets, 2016). In relation to supervisor's encouragement and motivation, the James and Baldwin (1999) framework on good practice of postgraduate supervision offered 11 practices that characterize effective supervisor. Some of these are presented below:

- Encourage students to publish their work early in their academic life and often. Get students involved in the life of the department,

- Inspire and motivate students,

- Help if academic and personal crises crop up,

- Take an active interest in students' future careers (Van Rensburg et al., 2016).

Based on the above framework, supervisors should go beyond supervising students for thesis or dissertation writing. They should serve as an inspiration and motivator for students to improve the totality of their academic skills and prepare for a career. Again, according to this framework, supervisors should enable students to realise their potential and even render help in solving personal crises, if needed. This aligns with the "policy cycle" mentioned previously.

In light of the literature and findings on the challenges and problems encountered by the international students in their studies in Malaysia, the researchers found few studies that specifically focused on their perceptions of research supervision, supervisors' content knowledge, availability for consultation, encouragement, and contribution to the students' academic and career growth. Previous studies tended to focus on sociological, psychological, and economic factors that affected international students in Malaysia, and not on the academic status or achievement of international students in Malaysia, which was the reason these young people chose Malaysia as their educational destination. Studies should examine the academic and research progress of international students in Malaysia progress, as well as the critical relationship with their supervisors.

To fill the gap in the research, this study aimed to explore international students' perceptions toward research supervision in Malaysia, relationships with their supervisors, environment and facilities, while proposing the RSEECKA mode (standing for relationships, supervision, environment; encouragement; content knowledge and availability) for best supervision practices. With the nature of this study as a predictive-based model, this study is guided by the following hypothesizes: 


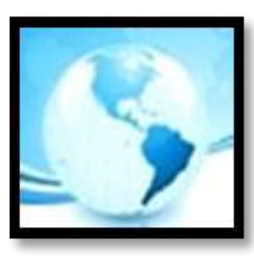

\section{MALAYSIAN ONLINE JOURNAL OF EDUCATIONAL MANAGEMENT (MOJEM)}

$\mathbf{H}_{\mathbf{i}} \mathbf{1}$ : There is a significant direct-effect of research supervision, supervisor's encouragement, content knowledge, availability; environment-facilities on international students' academic and career growth.

$\mathbf{H}_{\mathrm{i}}$ : : The R-SEECKA model can be used to describe variables that can contribute to effective research supervision and practice in Malaysia public universities.

\section{THEORETICAL AND CONCEPTUAL MODEL}

Constructing a predictive model for effective supervision practices, especially for international students, can be a daunting task. No single model currently used can sufficiently meet all supervision expectations of international students. The model that most closely predicts effective practices among supervisors of graduate students is the qualities model that Wiske (1997) created. Based on the premise that emotional intelligence and flexibility are important qualities for working with research students, this model suggests that a supervisor should be capable of gauging a student's level of independence in terms of conducting his/her own research activities. This would enable a postgraduate student to develop research qualities at a measured pace, with neither overdependence on, nor neglect by, his/her supervisor. This is because a supervisor would possess a range of experiences from which to draw upon, while a student would naturally develop personal awareness and capabilities for research needs.

One should not forget the contribution of research supervision theory and practice by Delamont, Atkinson and Parry, 2004; Punch, 2000, 2003; McWilliam and Singh, 2002; Zuber-Skerritt, 1992, which encourage and guide research supervision and the issues confronting student-supervisor relationships (Maxwell \& Smyth, 2011; Nightingale \& Wisker, 2005). Furthermore, social-constructivism theory and dynamic facilitation also contributed to the effectiveness of postgraduate supervision and practice. Dynamic facilitation practice is supervision based on social constructivism. It is highly recommended when it comes to knowledge generation at high level, intellectual growth, and development of postgraduate students' research project (Quan-Baffour \& Vambe, 2008).

In many situations, the traditional mode of supervision is used by faculty. Based on behaviourist theories of learning, this method tends to disempower students due to the supervision focusing only on technical aspects of the research, thesis production, and ensuring student, not on what supervisees have learned (Cadman \& Ha, 2001; Schulze, 2012; Zuber-Skerrit \& Roche, 2004). Therefore, it is recommended to use a socio-constructivist approach in supervision to empower students and to discover their capabilities in critically questioning dominant beliefs (Schulze, 2012).

Drawing on the model of supervision discussed above, the theoretical framework for this current research includes indicators that portray efficient supervision, specifically for international graduate students. This is called RSEECKA, after the elements that must be in place if the system of supervision is to produce the desired outcomes for graduate students. Those outcomes would be research production and dissemination, personal and professional adaptation to the academic environment, timely completion of the graduate program, and intellectual and emotional development and career advancement. The elements in the R-SEECKA model are: (1 and 2) relationship with a faculty member in which both the parties are diligent and dedicated to timely and meaningful progress toward the $\mathrm{MA} / \mathrm{PhD}$ and to the production of high-quality scholarship; supervision that is student-centred and meets the advisee's needs ( 3 and 4) an environment, with the good facilities in which graduate students are given the physical and emotional resources they need to adapt to and thrive in a scholarly community outside their home country; encouragement, motivation, support, availability, sensitivity, assistance and acceptance (5 and 6) the supervisor's extensive and cumulative content knowledge in the discipline, evidenced by recent publications, presentations and grants and availability of the supervisor and the creation of a mutually satisfactory.

Once the elements in the R-SEECKA model are in place, a postgraduate student will feel encouraged, motivated, supported, and accepted by the supervisor and the academic community in the host country. This should give a postgraduate student the confidence and capability to achieve the goals of every MA/PhD candidate - the timely 


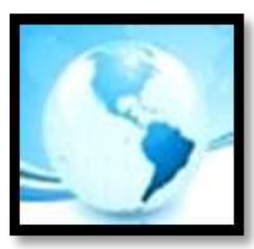

\section{MALAYSIAN ONLINE JOURNAL OF EDUCATIONAL MANAGEMENT (MOJEM)}

completion of the program, production of significant research that contributes to the field of study, being recognized as part of the community of scholars, and adaptation to the demands of academia and to the culture of the host country. Figure 1 below shows the R-SEECKA model.

This model also envisions that the supervisor's content knowledge of the supervisee's work, proper or effective supervision, university environment-facilities, relationship between supervisor and supervisee and the constant encouragement given by the supervisor to the student play big roles in the supervisee's achievement and personal growth. All these efforts are assumed to meet the high expectations of students and to trigger their determination.

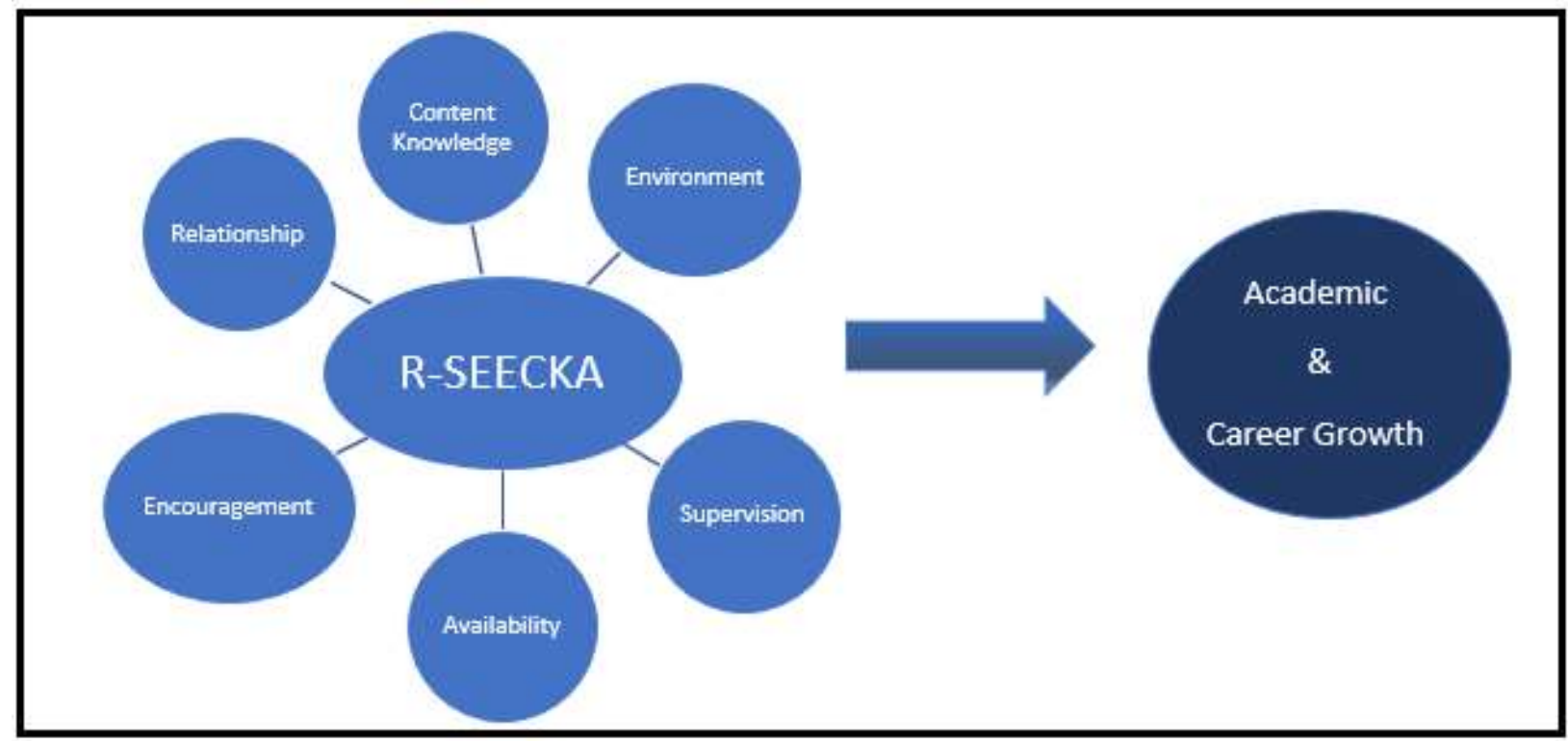

Figure 1. Research Hypothesized Model (R-SEECKA)

\section{METHODS}

\section{Sampling and Sample Size}

This study used a quantitative approach. The population consisted of postgraduate international students studying at six Malaysian public universities. These universities were selected due to the sizeable numbers of international students enrolled in their postgraduate programmes. Three of these universities are research universities, while other two are specialised universities. This study divided international students into geographical groups, based on continent of origin (Africa, Asia, Europe and the Americas), for a stratified random sample. Each continent was considered as a stratum in order to take a sample size or representative. Eventually, there were four strata (Africa, Asia, Europe and Americas). Because of a low response rate for the computer-generated survey, researchers opted for face-to-face administration. These resulted in 450 surveys completed by international students. The sample from each university varied in home countries due to their international student population.

\section{Instrument}

This study uses a survey instrument adapted from several questionnaires on research supervision of postgraduate students. Twenty-three of the questions came from the 44-question University of Sydney Survey of Higher Degree Research Students (2010). The University of Sydney used this survey to gather more information about what postgraduate students are experiencing, with the aim of improving services for future research students. Thus, the survey was part of university efforts to ensure the highest provision of education and quality (Institute for 


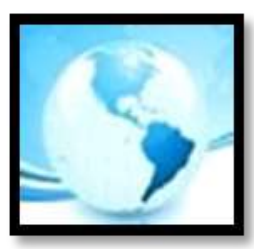

\section{MALAYSIAN ONLINE JOURNAL OF EDUCATIONAL MANAGEMENT (MOJEM)}

Teaching and Learning, 2010) Another 19 questions were adapted from the Student Perceptions of Research Supervision instrument developed at the Centre for Staff Development at the University of Western Australia (2001). The instrument explored the supervision process and the level of the relationship between students and their supervisors at the University of Western Australia to improve communication between supervisor and supervisee.

This study also included a total of 11 modified questions from the 69 in the survey of the Oxford Institute for the Advancement of University Learning (2005), titled "The Research Experience of Postgraduate Research students at the University of Oxford." The purpose of this instrument, according to Keith Trigwell and Harriet Dunbar-Goddet, was to discover the level of satisfaction of students with their research experience, research supervision, relationship with their supervisors, and the support system provided at Oxford University. This current study modified 18 items from the Victoria University's Graduate Research Student Questionnaire, which had 26 closedended questions (Guthrie \& Edge, 2015). This instrument was used to get feedback from Victoria University students and their experience of working with their Principal Research Supervisor. Four additional questions were adapted from The Supervisory Relationship Questionnaire, with 67 items (Palomo, Beinart, \& Cooper, 2010). The instrument was designed to investigate students' perceptions of research supervision and the relationship with their supervisors. During the pre-survey analysis some items were dropped, resulting in the final 68-question survey.

\section{Analytical Design}

The study used a structural equation model (SEM), with SmartPLS, to determine the effect of independent variables (exogenous) on dependent variables (endogenous). Independent variables were the basic elements in the R-SEECKA model. These were the supervisor's content knowledge, research environment/facilities, encouragement, relationship, availability, and supervision. The dependent variables were academic and career growth. Partial Least Squares is an alternative technique for SEM, used to develop theories in explanatory research by focusing on explaining the variance (prediction of the construction) in the dependent variables when examining the model. PLS-SEM is covariance-based approach to SEM and focuses on two models: the structural model and the measurement model.

\section{RESULTS}

\section{Demographic Data}

The survey provided demographic information indicating that $72.7 \%(n=328)$ of the respondents were male, while $27.3 \%$ ( $n=125$ ) were female. With respect to areas of study, 38.8\% ( $n=175)$ were from business, $31.3 \%$ ( $n=141$ ) were from the social sciences, while $29.9 \%(n=135)$ were from the natural sciences. With respect to degree level, $61 \%(n=275)$ of the respondents were PhD Candidates, while $39 \%(n=176)$ were master's students. With respect to academic level $59.6 \%(n=269)$ were in the third semester and above, $34.4 \%(n=155)$ were in the second semester, while only $6 \%(n=27)$ were in the first semester. In terms of nationality and continent, 58.6\% $(n=264)$ were East and South Asians (e.g. Arabs, Indians, Pakistan, Bangladeshi, Indonesians and others), 31.3\% were Africans (e.g. from Nigerian, Guinea, Senegal, Somalia and others) while $10.1 \%$ ( $n=46$ ) were from Europe (e.g. Bosnia and Turkey).

\section{Assessing Measurement Model}

This study used a measurement model to determine if the items or indicators were loaded under their respective constructs. To determine the validity of the items, convergent validity was checked and, according to convergent validity's criteria, all items should be significant and more than 0.70. Additionally, according to Fornell and Larcker (1981), the Average Variance Extracted (AVE) should be more than 0.50 (or the square root of AVE > 0.707), while 


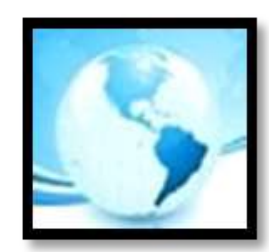

\section{MALAYSIAN ONLINE JOURNAL OF EDUCATIONAL MANAGEMENT (MOJEM)}

according to Hair, Black, Balin, and Anderson 2010), the composite reliability index for each construct should be greater than 0.70 .

To determine the internal consistency, composite reliability was checked, and Table 1 shows that the values of the composite reliability values of latent variables were between .934 and .989, which, according Hair, Hult, Ringle, and Sarstedt (2014), indicates high reliability. This study also met the minimum criteria as the AVE values were all more than the acceptable threshold of 0.5, confirming convergent validity (Fornell \& Larcker, 1981; Guo, Yuan, Archer, \& Connelly, 2011). Table 1 and figure 2 below show the outer loadings from PLS and reveal that convergent validity was satisfactorily achieved; all the loadings of items were more than 0.70 and all were significant. This study also met the criterion for necessary to achieve discriminant validity.

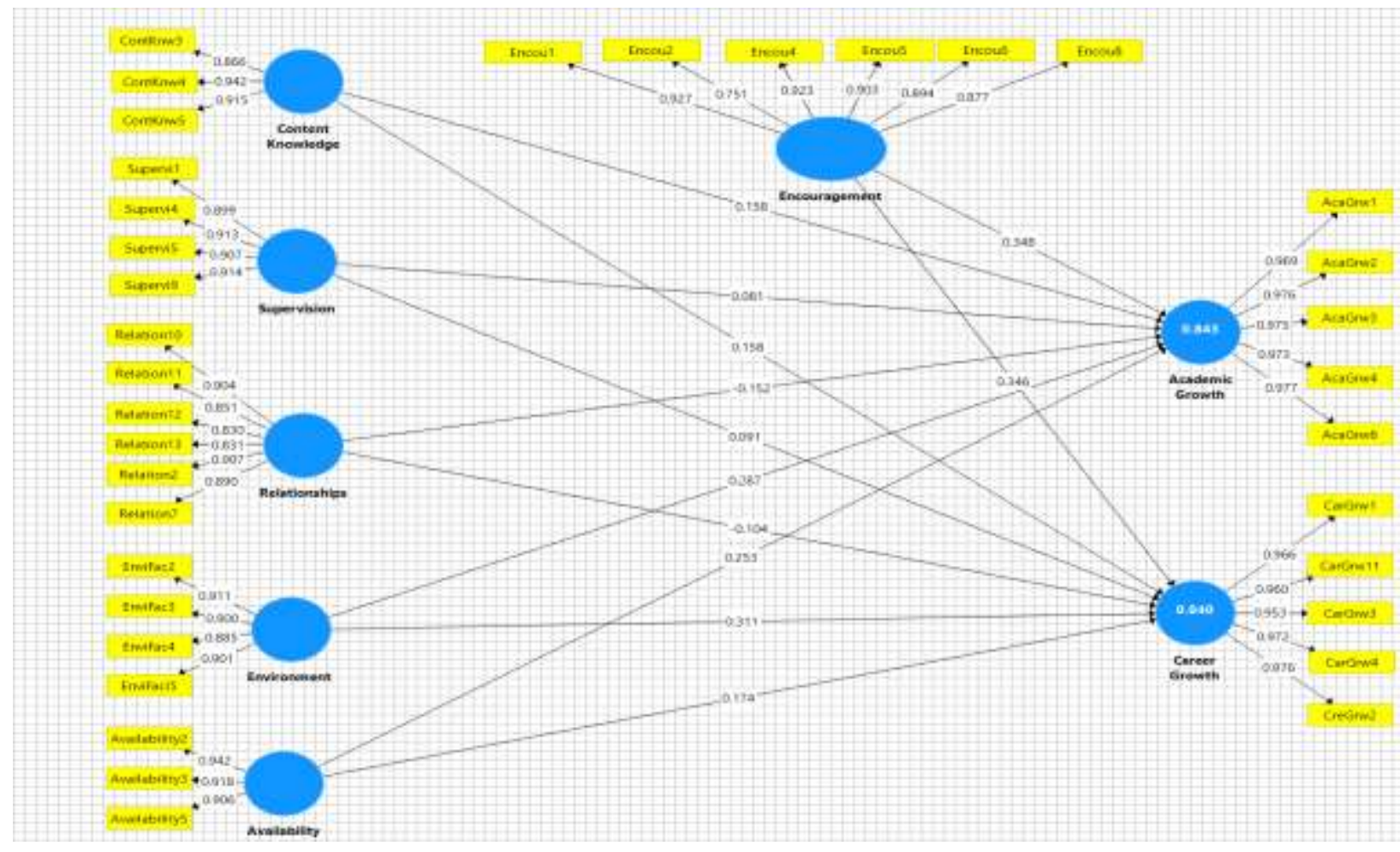

Figure 2. Outer Loading for Measurement Model 


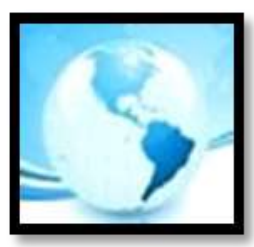

MALAYSIAN ONLINE JOURNAL OF

EDUCATIONAL MANAGEMENT

(MOJEM)

Table 1

Formative Outer Measurement Model Assessment (Factor Loading, Reliability \& Validity)

\begin{tabular}{|c|c|c|c|c|c|}
\hline Research Variables & Loadings & $\begin{array}{l}\text { Cronbach's } \\
\text { Alpha }\end{array}$ & $\begin{array}{l}\text { Composite } \\
\text { Reliability }\end{array}$ & $\begin{array}{l}\text { Discriminant } \\
\text { Validity }\end{array}$ & $\begin{array}{l}\text { Average } \\
\text { Variance } \\
\text { Extracted }\end{array}$ \\
\hline Encouragement & & 0.942 & 0.954 & 0.881 & 0.777 \\
\hline Encou1 & 0.927 & & & & \\
\hline Encou2 & 0.951 & & & & \\
\hline Encou4 & 0.923 & & & & \\
\hline Encou5 & 0.903 & & & & \\
\hline Encou6 & 0.894 & & & & \\
\hline Encou8 & 0.877 & & & & \\
\hline $\begin{array}{l}\text { Relationship between } \\
\text { Supervisor \& Supervisee }\end{array}$ & & 0.929 & 0.949 & 0.869 & 0.756 \\
\hline Relation2 & 0.907 & & & & \\
\hline Relation7 & 0.890 & & & & \\
\hline Relation10 & 0.904 & & & & \\
\hline Relation11 & 0.851 & & & & \\
\hline Relation 12 & 0.830 & & & & \\
\hline Relation13 & 0.831 & & & & \\
\hline Research Environment & & 0.921 & 0.944 & 0.899 & 0.809 \\
\hline ResEnvFac1 & 0.897 & & & & \\
\hline ResEnvFac11 & 0.875 & & & & \\
\hline ResEnvFac12 & 0.889 & & & & \\
\hline ResEnvFac3 & 0.877 & & & & \\
\hline ResEnvFac4 & 0.897 & & & & \\
\hline ResEnvFac6 & 0.903 & & & & \\
\hline ResEnvFac9 & 0.887 & & & & \\
\hline $\begin{array}{l}\text { Supervisor's Research } \\
\text { Content Knowledge }\end{array}$ & & 0.894 & 0.934 & 0.908 & 0.825 \\
\hline ContKnw3 & 0.866 & & & & \\
\hline ContKnw4 & 0.942 & & & & \\
\hline ContKnw8 & 0.904 & & & & \\
\hline Research Supervision & & & 0.950 & 0.908 & 0.825 \\
\hline Supervi1 & 0.899 & & & & \\
\hline Supervi4 & 0.913 & & & & \\
\hline Supervi5 & 0.907 & & & & \\
\hline Supervi9 & 0.914 & & & & \\
\hline Supervisor's Availability & & 0.912 & 0.944 & 0.922 & 0.850 \\
\hline Availability 2 & 0.942 & & & & \\
\hline Availability 3 & 0.918 & & & & \\
\hline Availability 5 & 0.906 & & & & \\
\hline Career Growth & & 0.982 & 0.986 & 0.965 & 0.932 \\
\hline CarGrow1 & 0.966 & & & & \\
\hline CarGrow2 & 0.960 & & & & \\
\hline CarGrow3 & 0.953 & & & & \\
\hline CarGrow4 & 0.972 & & & & \\
\hline
\end{tabular}




\begin{tabular}{|c|c|c|c|c|c|}
\hline CarGrow11 & 0.906 & & & & \\
\hline Academic Growth & & 0.986 & 0.989 & 0.974 & 0.948 \\
\hline AcaGrow 1 & 0.969 & & & & \\
\hline AcaGrow 2 & 0.966 & & & & \\
\hline AcaGrow 3 & 0.975 & & & & \\
\hline AcaGrow 4 & 0.973 & & & & \\
\hline AcaGrow 6 & 0.977 & & & & \\
\hline
\end{tabular}

\section{Assessing the Structural Model}

To determine if a significant direct effect existed between the exogenous (independent) and endogenous (dependent) variables, standardized path coefficients were checked by looking at the R2 values. To estimate the significance of the paths in the model, the researchers ran a bootstrapping re-sampling procedure (with 500 samples). In relationship to $R^{2}$ of the model, the exogenous variance, explained by the model $\left(R^{2}\right)$ on endogenous constructs, yielded a value of 0.845 for academic growth and 0.843 for career growth. This is equivalent to $84 \%$ variance, as can been seen in Figure 2, which fulfilled Falk and Miller's (1992) requirement that the $R^{2}$ value of a dependent variable should be at least $10 \%$ to make any meaningful interpretation.

Figure 3 and Table 2 show that environment-facilities has a significant direct-effect on academic growth $(\beta=$ $0.287, T=5.502, p<0.000)$ and career growth $(\beta=0.311, T=6.130, p<0.000)$; availability of the supervisor on academic growth $(\beta=0.253, T=4.279, p<0.000)$ on career growth $(\beta=0.174, T=2.939, p<0.003)$; content knowledge of the supervisor on academic growth $(\beta=0.158, T=2.619, p<0.009)$ on career growth $(\beta=0.158, T=$ $2.961, p<0.006)$; encouragement by the supervisor on academic growth $(\beta=0.348, T=4.234, p<0.000)$ on career growth $(\beta=0.346, T=4.786, p<0.000)$ and relationship between the advisor and advisee on academic growth $(\beta=0.152, T=2.220, p<0.027)$. Only research supervision failed to have a significant direct effect on academic and career, as did the relationship between supervisor and supervisees on career growth.

The impact of research supervision on students' academic and career growth may have failed to reach significance because most postgraduate students in Malaysia have taken courses on research methodology and data analysis in their home countries as prerequisite before starting their master's or PhD programme. Many doctorate-seeking international students in Malaysia have master's degrees. As a result, they may have had experience in research methodology, data analysis, and technical writing, and do not need much supervision in these areas. 


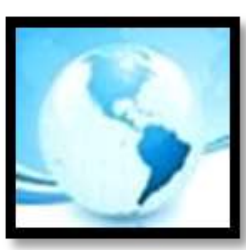

MALAYSIAN ONLINE JOURNAL OF EDUCATIONAL MANAGEMENT (MOJEM)

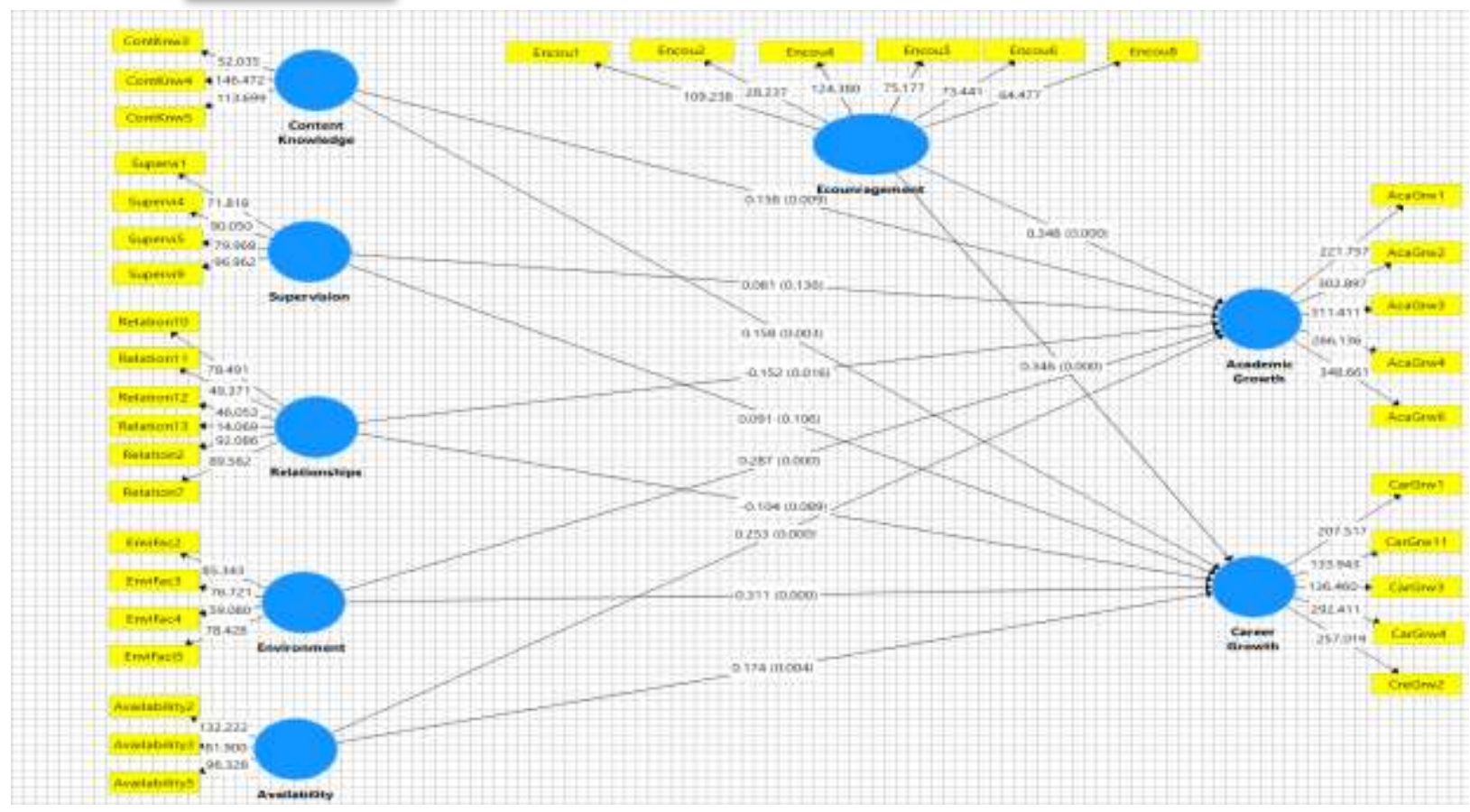

Figure 3. Structural Model and Path Analysis ( $\beta$ )

\section{Predictive Relevance of the Model $\left(Q^{2}\right)$}

To measure the quality of the PLS path model, $\mathrm{Q}^{2}$ is determined by running blindfolding in the SmartPLS application. $Q^{2}$ is a criterion applied when aiming to know the impact of exogenous on endogenous. The value is expected to be greater than zero. As for this study, the $Q^{2}$ value for academic growth was equal to 0.796 and career growth was 0.779 , which were both higher than the threshold limit while supporting the predictive relevance adequacy. When it comes to determining the predictive construct that has a great impact on international graduate students' academic and career growth, Figures 2, 3 and Table 2 illustrate that, the research or university environment tends to have the greatest effect on both academic and career growth, followed by supervisor's encouragement and motivation to students during the supervision. Also, availability of the supervisor shows a great impact on international graduate students' academic and career growth, as does the supervisor's content knowledge.

Table 2

T-Statistics of Path Coefficients and P-Values

\begin{tabular}{lccc}
\hline & $T$ & $P$-Values & Results \\
\hline Availability -> Academic Growth & Statistics & & Supported \\
Availability -> Career Growth & 4.279 & 0.000 & Supported \\
Content Knowledge -> Academic Growth & 2.939 & 0.003 & Supported \\
Content Knowledge -> Career Growth & 2.619 & 0.009 & Supported \\
Encouragement -> Academic Growth & 2.961 & 0.003 & Supported \\
Encouragement -> Career Growth & 4.234 & 0.000 & Supported \\
Environment -> Academic Growth & 4.786 & 0.000 & Supported \\
Environment -> Career Growth & 5.502 & 0.000 & Supported \\
Relationships -> Academic Growth & 6.130 & 0.000 & Supported \\
Relationships -> Career Growth & 2.220 & 0.027 & Not Supported \\
\hline
\end{tabular}




\section{DISCUSSION}

The results of the study showed several things. First, the survey on research supervision given to a sample of international graduate students in Malaysia noted that the research environment-facilities was the most crucial factor in the R-SEECKA model in enabling them to progress in their academic and career growth in the host institution. As examined in this study, the research environment included facilities, a supportive working environment, and a community of scholars, seminar programs, and intellectual life. Not surprisingly, the students surveyed believed that these provided the impetus for them to achieve their personal academic goals. In no small measure, research is "poetry of place." When a sufficient intellectual critical mass is developed, students and faculty are encouraged in their efforts. Often research is a collaborative effort in which ideas are traded and expanded in a climate of collective learning that includes meetings, informal gatherings, and seminars. Additionally, having a place to work and the proper tools to work with makes the process easier and more efficient, which provides motivation for students to complete their studies in a timely manner. This current findings with the work are in line if Sidhu et al. (2013) on postgraduate supervision among Malaysians, which reported research environment and lack of institutional support as some of the challenges faced Malaysians postgraduates.

Second, supervisor's encouragement-motivation, another element in the R-SEECKA model, was also critical with respect to student academic and career growth. When the students are encouraged and motivated, they tend to do their possible best. These findings are related to the research results of Åkerlind and McAlpine (2015). Encouragement is one of the factors emphasized in the UK's policy cycle and James and Baldwin's (1999) research framework, as reported by Van Rensburg et al. (2016). In addition, supervisor's availability was the third factor to be considered in student academic and career growth. The responsiveness and availability of a supervisor in providing meaningful feedback, through regular consultations, emails and telephone calls is seen as helpful. The current findings on supervisor accessibility aligns with researches by Krauss and Ismail (2010), Al-Naggar et al. (2012), alongside Ali et al. (2016). They all emphasized on the importance of supervisor's availability and accessibility for postgraduates graduating on time.

Lastly, a supervisor should read graduate student work in a timely and helpful manner and provide assistance at critical intervals for proposal defences and VIVAs. Fourth was the content knowledge of the supervisor. This meant that the supervisor was interested and well informed about the topic of the student's project, having academic or professional experience in areas related to the topic, such as the organizational system, location, or environment in which the research is set. The supervisor must have mentored several postgraduate students in general and, specifically, in the research area that is the focus of the advisee's work. Moreover, the supervisor must be responsive and responsible, available to work with the student in a timely and meaningful manner.

Surprisingly, research supervision tends to play insignificant role in international graduate students' academic and career growth. This has been explained in the findings section. However, this study did not investigate the direct involvement of the supervisor in all phases of the supervisee's research project, from selecting the topic to defending the proposal, as a critical factor in the production of important research, matriculation, acceptance in the community of scholars, and adaptation to the academic environment of the host country. One reason may be that many international graduate students may not need as such supervision from their supervisors as do their domestic peers. Concerned about finances in the home and host countries, burdened by family expectations, socially isolated due to cultural differences with other students, these young people are internally motivated to succeed academically. Many foreign postgraduates do not need a supervision from their supervisors to have a sense of belonging and social integration within their academic departments (Curtin et al., 2013). Based on these 


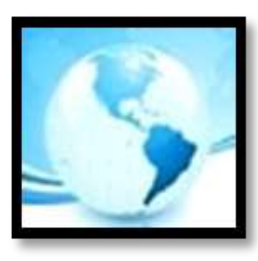

\section{MALAYSIAN ONLINE JOURNAL OF EDUCATIONAL MANAGEMENT (MOJEM)}

findings, then, research or university environment-facilities, the supervisor's encouragement, content knowledge, availability and relationship looked more important than any other factor or variable.

\section{CONCLUSION AND RECOMMENDATIONS}

It seems that what counts are the supervisor's encouragement, motivation, research, and professional qualifications, availability, and relationship with the student. Also important is the research environment and facilities. Soft skills are great, and they need to be culturally responsive, but what an international student really wants is to have a supervisor who will help the him or her get that degree. Although research supervision had an insignificant direct effect on the academic and career growth of international postgraduate students, the nature of the relationship between supervisor and student is vitally important. In the context of this survey, this finding means that students were more concerned with soft interpersonal skills than they were with hard skills present in actual supervision.

This study has also contributed the gap in the literature by adding new findings to the body of knowledge on postgraduate supervision in Malaysia and in other contexts, especially the importance of supervisor's encouragement and motivation, environment and facilities; content knowledge and the supervisor's background in the student's area of study, as well as supervisor availability and relationship with the student. Thus, supervision, according to R-SEECKA, is not only meant for supervisor who is following up the progress of his/her supervisees, providing information and mentorship, and supporting supervisees' research. Rather, it reveals the importance of other factors: encouraging and motivating postgraduate students, ensuring a conducive environment for them, a deep knowledge of what the supervisee is doing, establishing and maintaining a relationship with the supervisee, and being available for consultation.

This study adds to the conversation about graduate education, with respect to mentorship, graduate supervision, and the critical nature of overall research support, and how these factors contribute to the creation of an environment in which international graduate students can succeed. Based on the R-SEECKA model, the study offers important findings for the care and nurturing of international graduate students. Among them is that the matching process between academic supervisor and supervisee must be conducted carefully. Also, students must be provided with adequate facilities, but, more importantly, must feel a sense of community to complete their projects and move forward in their careers. The didactic relationship between supervisor and supervisee is arguably among the most critical elements for graduate student academic success.

The Malaysian government should embrace the primary objective of international students in coming to Malaysia, which is education. Since most international students are at the postgraduate level in Malaysian universities, extending quality service and sustainability should begin with academic wellbeing and research development. The progress that they are making in their thesis or dissertation research and writing, research supervision, and graduating on time should be priorities. Although geared to the Malaysian context, the results of the current study point to the immense value of a proper match between supervisor and supervisee, particularly with respect to international students who often feel like "strangers in a strange land," both as graduate students and as international visitors settling into an unfamiliar environment.

\section{DIRECTIONS FOR FUTURE RESEARCH}

Regardless of context, an academic supervisor's research environment, availability, content knowledge, pedagogical skills and close relationship with a supervisee are very crucial to research completion and graduation on time. Unfortunately, there is little current research on academic in higher education, despite the challenges facing graduate students, especially those from foreign countries in finding supervisors that share the student's research interests. There need to be more studies on international students' research and academic expectations 


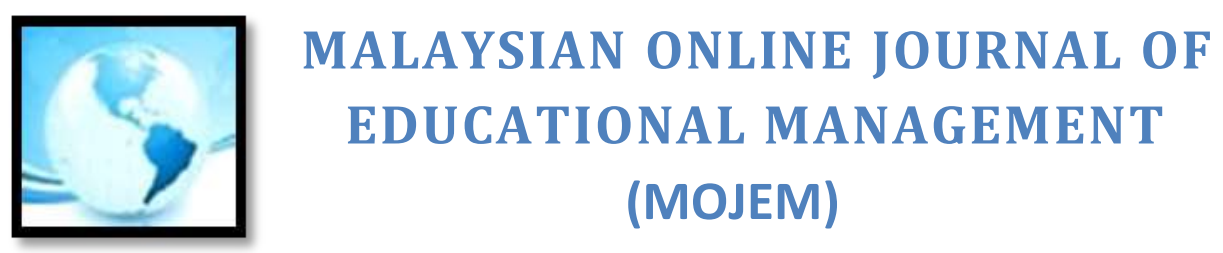

at their academic destinations, as international students' mobility has become a means for countries to improve their economies and reputations.

Therefore, future research could expand upon this study. Data could be broken down by student country of origin to determine the differences, if any, between and among students from different parts of the world. The variables in the R-SEECKA model should be refined and closely examined. This is especially true of "supervision." It is counter-intuitive that timely and meaningful involvement by the supervisor in the student's program of study is not significant.

Additionally, because the supervisor-supervise is a dyadic relationship, this relationship might be studied through the lens of Leader-Member Exchange Theory (LMX). This is a relationship-based theory that looks at the dyadic relationship between leaders and their subordinates, concluding that the quality of that exchange relationship influences the responsibility, decisions, and access to resources and performance of subordinates, such as students (Bauer \& Erodogen, 2015). Studies have shown that leader-member exchange may promote positive experiences and augment organizational effectiveness (Liden, Sparrowe, \& Wayne, 1997). Lastly, such research should be conducted in a longitudinal manner. As education becomes global, studies should be conducted to see if and how changes in student perceptions about their needs and desires changes over time.

\section{REFERENCES}

Åkerlind, G., \& McAlpine, L. (2015). Supervising doctoral students: variation in purpose and pedagogy. Studies in Higher Education, 42 (9), 1-13. doi: 10.1080/03075079.2015.1118031

Alam, F., Alam, Q., \& Rasul, M. G. (2013). A pilot study on postgraduate supervision. Paper presented at the 5th BSME International Conference on Thermal Engineering, Bangladesh.

Ali, P. A., Watson, R., \& Dhingra, K. (2016). Postgraduate research students' and their supervisors' attitudes towards supervision. International Journal of Doctoral Studies, 11, 227-241. Retrieved from http://www.informingscience.org/Publications/3541

Al-Naggar, R. A., Al-Sarory, M., Al-Naggar, A. A., \& Al-Muosli, M. (2012). Doctorate international students' satisfaction and stress on academic supervision in a Malaysian University: a qualitative approach. Educational Research, 3(3), 264-269

Andreotti, V. (2011). Relativizing western knowledge production in spaces of dissensus. The OSDE methodology. In V. Andreotti (Ed.), Actionable postcolonial theory in education (pp.191-216). Retrieved from http://www.palgraveconnect.com/pc/doifinder/10.1057/9780230337794.0020

Bauer, T., \& Erodogen, B. (2015). The Oxford handbook of leader-member exchange. New York, New York: Oxford University Press.

Cadman, K., \& Ha, T. H. (2001). 'Only connect': Transcultural supervision as the 'Rainbow Bridge'. In A. Bartlett \& G. Mercer (Eds.), Postgraduate Research Supervision: Transforming Relations (pp. 215 - 232). New York: Peter Lang.

Chiappetta-Swanson, C., \& Watt, S. (2011). Good practice in the supervision and mentoring of postgraduate students: It takes an academy to raise a scholar. Retrieved from https://cll.mcmaster.ca/resources/pdf/Supervision\%20and\%20Mentoring\%20of\%20Postgrad\%20Students. pdf

Cinar, Z. (2007). Coaching and mentoring. Paradox: Economics, Sociology and Policy Journal, 3(1), 1-25.

Clutterbuck, D. (2004). Everyone needs a mentor ( $4^{\text {th }}$ ed.). London, England: CIPD House.

Curtin, N., Stewart, A., \& Ostrove, J. (2013). Fostering academic self-concept advisor support and sense of belonging among international and domestic graduate students. AERA Journal, 50(1), 108-137.

Delamont, S., Atkinson, P., \& Parry, O. (2004). Supervising the doctorate: A guide to success (2nd ed.). New York: Society for Research into Higher Education and Oxford University Press. 


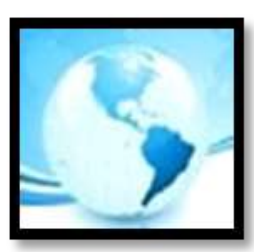

MALAYSIAN ONLINE JOURNAL OF

EDUCATIONAL MANAGEMENT

(MOJEM)

Donald, J. G., Saroyan, A., \& Denison, D. B. (1995). Graduate student supervision policies and procedures: A case study of issues and factors affecting graduate study. Canadian Journal of Higher Education, 25(3), 71-92.

Donnelly, R. (2012). Enabling connections in Postgraduate Supervision for an applied eLearning professional development programme. International Journal for Academic Development, 18 (4), 356-370

Falk, R. F., \& Miller, N. B. (1992). A primer for soft modeling. Akron, Ohio: University of Akron Press.

Fornell, C., \& Larcker, D. F. (1981). Evaluating structural equation models with unobservable variables and measurement error. Journal of Marketing Research, 18(3), 39-50.

Ghadirian, L., Sayarifard, A., Majdzadeh, R., Rajabi, F., \& Yunesian, M. (2014). Challenges for better thesis supervision. Medical Journal of the Islamic Republic of Iran, 28 (32), 1-9

Grant, K., Hackney, R., \& Edger, D. (2014). Postgraduate research supervision: An 'Agreed' conceptual view of good practice through derived metaphors. International Journal of Doctoral Studies, 9, 43-60.

Guo, K. H., Yuan, Y., Archer, N. P., \& Connelly, C. E. (2011). Understanding non-malicious security violations in the workplace: A composite behavior model. Journal of Management Information Systems, 28(2), $203-236$.

Guthrie, B., \& Edge, N. (2015). Australian Graduate Survey $2015 . \quad$ Retrieved from https://www.airweb.org/AboutUs/History/Documents/GCA_2014_AGS_Report_FINAL.pdf

Guven, E. (2014). The evaluation of relationship between research assistants and consultants in the frame of mentoring (Unpublished Master's Thesis). Sakarya University, Educational Sciences Institute Sakarya, Turkey.

Hair, J. F., Black, W. C., Balin, B. J., \& Anderson, R. E. (2010). Multivariate data analysis. New York: Maxwell Macmillan International Editions.

Hair, J. F., Hult, G. T. M., Ringle, C. M., \& Sarstedt, M. (2014). A primer on partial least squares structural equation modeling (PLS-SEM). New York : Sage.

Halse, C. (2011). 'Becoming a supervisor': The impact of doctoral supervision on supervisors' learning. Studies in Higher Education, 36(5), 557-570.

Hamilton, L., \& Carson, S. (2015). Supervising Practice: Perspectives on the supervision of creative practice higher degrees by research. Educational Philosophy and Theory, 47:12, 1243-1249, DOI: 10.1080/00131857.2015.1094904

Higher Education Academy. (2014). supervision from. https://www.heacademy.ac.uk/system/files/resources/Supervision.pdf

Hodza, F. (2007). Managing the student-supervisor relationship for successful postgraduate supervision: A sociological perspective. South African Journal of Higher Education, 21(8), 1155-1165.

Holloway, E. L. (1995). Clinical supervision: A systems approach. Thousand Oaks, California: Sage.

Hunter, A. B., Laursen, S. L., \& Seymour, E. (2006). Becoming a scientist: The role of undergraduate research in students' cognitive, personal, and professional development. Science Education, 91, 36-74. doi:10.1002/sce.20173

Hussain, A. (2011). Supervision and evaluation of research projects of graduate students - Realities and requirements. Journal of Quality and Technology Management, 7(2), 123- 137.

ICEF Monitor. (2016). Malaysia competing for a greater share of international students. Retrieved from http://monitor.icef.com/2016/08/malaysia-competing-greater-share-international-students/.

Institute for Advancement of University Learning. (2005). The research experience of postgraduate research students at the University of Oxford. Retrieved from http://supervision.learning.ox.ac.uk/sites/default/files/The_Research_Experience_of_Postgraduate_Reseac h_Students_at_Oxford.pdf

Institute for Teaching and Learning. (2010). 2010 survey of higher degree research students. Retrieved from https://sydney.edu.au/education-portfolio/qa/sreq/2010_SREQ_questionnaire.pdf

Ismail, A., Abiddin, N. Z., \& Hasan, A. (2011). Improving the development of postgraduates' research and supervision. International Education Studies, 4(1), 78-89.

James, R., \& Baldwin, G. (1999). Eleven practices of effective postgraduate supervisors Retrieved from http://www.Icad.icmc.usp.br/ buscaglia/links/sistcient/11practices.pdf. 


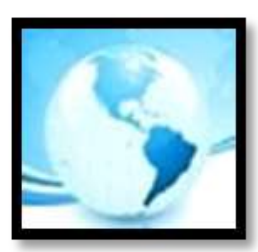

\section{MALAYSIAN ONLINE JOURNAL OF EDUCATIONAL MANAGEMENT (MOJEM)}

Jonson, K. F. (2008). Being an effective mentor: How to help beginning teachers succeed. California: Corwin Press.

Liden, R. C., Sparrowe, R. T., \& Wayne, S. J. (1997). Leader-member exchange theory: The past and potential for the future. In G. R. Ferris and K. M. Rowland (Eds.), Research in personnel and human resources management (pp. 47-119). Greenwich, Connecticut: JAI Press.

Karakose, T., Yirci, R., Uygun, H., \& Ozedmir, T. Y. (2016). Post-graduate students' perceptions regarding effectiveness of mentoring relationship at universities. Revista de Cerceteare Sociali, 52, 252-264

Krauss, S. E., \& Ismail, I. A. (2010). PhD students' experiences of thesis supervision in Malaysia: Managing relationships in the midst of institutional change. The Qualitative Report, 15 (4), 802-822

Lovitts, B. E. (2001). Leaving the ivory tower: The causes and consequences of departure from doctoral study. Lanham, Maryland: Rowman and Littlefield.

McWilliam, E., \& Singh, P. (2002). Towards a research training curriculum: What, why, how, who? Australian Educational Researcher, 29(3), 3-18.

Malfroy, J. (2005). Doctoral supervision, workplace research and changing pedagogic practices. Higher Education Research and Development, 24(2), 165-178.

Maxwell, T. W., \& Smyth, R. (2011). Higher degree research supervision: from practice toward theory. Higher Education Research \& Development, 30 (2), 219-231.

Mudhovozi, P., Manganye, L., \& Mashamba, T. (2017). Mentors' views of supervising postgraduate students undertaking research at an institution in Zimbabwe. Journal of Social Sciences, 37 (3), 293-300.

Nightingale, P. (2005). Advising PhD Candidates. Sydney: Higher Education Research and Development Society of Australasia Inc.

Omar, F., Mahone, J. P., Ngobia, J., \& FitzSimons, J. (2016). Building rapport between international graduate students and their faculty advisors: Cross- cultural mentoring relationships at the University of Guelph. Canadian Journal for the Scholarship of Teaching and Learning, 7(2), 1-17.

Othman, N. Z. (2015). Relationship between international students' experience, adjustment and academic performance in Malaysian public universities (Unpublished Master Dissertation). Universiti Sains Malaysia, Malaysia.

Palomo, M., Beinart, H., \& Cooper, M. (2010). Development and validation of the Supervisory Relationship Questionnaire (SRQ) in UK trainee clinical psychologists. British Journal of Clinical Psychology, 49, $131-149$. Retrieved from https://cedar.exeter. ac.uk/media/universityofexeter/schoolofpsychology/cedar/documents/dclinpsy2014/SRQ_PDF.pdf

Punch, K. F. (2000). Developing effective research proposals. London: Sage.

Punch, K. F. (2003). Survey research: The basics. London: Sage.

Quan-Baffour, K. P., \& Vambe, M. T. (2008). Critical issues in the Supervision of post-graduate dissertations in distance education environments. The Journal for Open and Distance Education and Educational Technology, 4 (1), 7-16.

Ramesh, V. (2014). Academic mentoring-Need of an hour. International Journal of Management and Social Science Research Review, 4, 111-119.

Roberts, L. D., \& Seaman, K. (2018). Good undergraduate dissertation supervision: Perspectives of supervisors and dissertation coordinators. International Journal for Academic Development, 23 (1), 28-40. doi: 10.1080/1360144X.2017.1412971

Schein, E. H. (1978). Career dynamics: Matching individual and organizational needs. Reading, Massachusetts: Addison-Wesley Publication.

Schulze, S. (2012). Empowering and disempowering students in student-supervisor relationships. Koers-Bullen for Chrisman Scholarship, 77(2), 1 - 8. hp://dx.doi.org/10.4102/koers.v77i2.47

Sidhu, G. A., Kaur, S., Fook, C. Y., \& Yunus, F. Y. (2013). Postgraduate Supervision: Exploring Malaysian students' experiences. Procedia - Social and Behavioral Sciences, 90, 133 - 141.

Tahir, I. M., Ghani, N. A., Atek, E. S. E., \& Manaf, Z. A. (2012). Effective supervision from research students' perspective. International Journal of Education, 4 (2), 211-222 
Terrell, S., Snyder, M., \& Dringus, L. (2009). The development, validation, and application of the doctoral student connectedness scale. Internet in Higher Education, 12(2), 112-116.

The Center for Staff Development at the University of Western Australia. (2001). Student Perceptions of Research Supervision (SPORS). Parallel questionnaires for students and supervisors. Retrieved from https://sydney.edu.au/education-portfolio/ei/supervision/files/spors.pdf

University of Nottingham Malaysia. (2015). MyMentor programme launched by Minister of Education II. Retrieved from http://www.nottingham.edu.my/NewsEvents/News/ 2015/MyMentor-programmed-launched-byMinister-of-Education-II.aspx

Van Rensburg, G. H., Mayers, P., \& Roets, L. (2016). Supervision of Post-graduate students in higher Education. Trends in Nursing, 3, (1). Retrieved from http://fundisa.journals.ac.za http://dx.doi.org/10.14804/3-1-55

Wang, T., \& Li, L. Y. (2014). Understanding international postgraduate research students' challenges and pedagogical needs in thesis writing. International Journal of Pedagogies and Learning, 4(3), 88-96.

Wiske, M. S. (1997). Teaching for understanding: Linking research with practice (1 $1^{\text {st }}$ ed.). San Francisco, California: Jossey-Bass.

Zuber-Skerritt, O. (Ed.). (1992). Starting research: Supervision and training. Brisbane: The Tertiary Education Institute, University of Queensland.

Zuber-Skerrit, O., \& Roche, V. (2004). A constructivist model for evaluating postgraduate supervision: A case study. Quality Assurance in Education, 12(3), 82-93.

Zuria, M., Salleh, A., Saemah, R., \& Noriah, M. I. (2010). Challenges for international students in Malaysia: Culture, climate, and care. Procedia Social and Behavioral Sciences, 7, 289-293. doi: 10.1016/j.sbspro.2010.10.040 